\title{
Influence of Carrier Filling Ratio on the Advanced Nitrogen Removal from Wastewater Treatment Plant Effluent by Denitrifying MBBR
}

\author{
Yuanzhe Zhao ${ }^{1,2}$, Quan Yuan ${ }^{1,2}$, Zan He ${ }^{1,3}$, Haiyan Wang ${ }^{1,2}, * \mathbb{1}$, Guokai Yan ${ }^{1,2}$, Yang Chang ${ }^{1,2}$, \\ Zhaosheng Chu ${ }^{1,4}$, Yu Ling ${ }^{1,2}$ and Huan Wang ${ }^{1,2}$ \\ 1 State Key Laboratory of Environmental Criteria and Risk Assessment, Chinese Research Academy of \\ Environmental Sciences, Beijing 100012, China \\ 2 Engineering Center for Environmental Pollution Control, Chinese Research Academy of Environmental \\ Sciences, Beijing 100012, China \\ 3 Beijing China's Sustainable Development Water Purification Material Technology Co., Beijing 100012, China \\ 4 National Engineering Laboratory for Lake Pollution Control and Ecological Restoration, Chinese Research \\ Academy of Environmental Sciences, Beijing 100012, China \\ * Correspondence: wanghy@craes.org.cn
}

Received: 12 July 2019; Accepted: 29 August 2019; Published: 4 September 2019

\begin{abstract}
The filling ratio (FR) of a carrier has an influence on the pollutant removal of the aerobic moving bed biofilm reactor (MBBR). However, the effect of the polyethylene (PE) carrier FR on the performance and microbial characteristics of the denitrifying MBBR for the treatment of wastewater treatment plant (WWTP) effluent has not been extensively studied. A bench-scale denitrifying MBBR was set up and operated with PE carrier FRs of $20 \%, 30 \%, 40 \%$, and $50 \%$ for the degradation of chemical oxygen demand (COD) and nitrogen from WWTP effluent at $12 \mathrm{~h}$ hydraulic retention time (HRT). The nitrate removal rates with FRs of $20 \%, 30 \%, 40 \%$, and $50 \%$ were $94.3 \pm 3.9 \%, 87.7 \pm 7.3 \%$, $89.7 \pm 11.6 \%$, and $94.6 \pm 4.0 \%$, and the corresponding denitrification rates $\left(\mathrm{r}_{\mathrm{NO}}-\mathrm{N}\right)$ were $8.0 \pm 5.6$, $11.3 \pm 4.6,11.6 \pm 4.6$, and $10.0 \pm 4.9 \mathrm{mg} \mathrm{NO}_{3}{ }^{-}-\mathrm{N} / \mathrm{L} / \mathrm{d}$, respectively. Nitrous oxide reductase (nos $\mathrm{Z}$ ) gene-based terminal restriction fragment length polymorphism (T-RFLP) analysis illustrated that the highest functional diversity (Shannon's diversity index, $\mathrm{H}^{\prime}$ ) of biofilm microbial community was obtained at $30 \%$ FR. The quantitative polymerase chain reaction (qPCR) results indicated that the abundance of nitrate reductase (narG) and nosZ genes at 30\% FR was significantly higher than that at $20 \% \mathrm{FR}$, and no significant changes were observed at $40 \%$ and $50 \%$ FRs. Thus, $30 \%$ FR was recommended as the optimal carrier FR for the denitrifying MBBR.
\end{abstract}

Keywords: denitrifying MBBR; polyethylene carrier; filling ratio; T-RFLP; qPCR

\section{Introduction}

High total nitrogen (TN) of wastewater treatment plant (WWTP) effluent is always the primary factor affecting its compliance with the discharge standards and recycling, because the TN standard for WWTP effluent (Class I-A, $15 \mathrm{mg} \cdot \mathrm{L}^{-1}$, SEPA of China, 2002) [1] is much higher than the maximum required TN value of natural surface water (Class V, $2.0 \mathrm{mg} / \mathrm{L}^{-1}$, SEPA of China, 2002) [2]. Therefore, it is very urgent to further remove the TN from WWTP effluent for the production of high-quality recycled water, which can be used as recharge water for rivers or groundwater in water shortage areas. The TN of WWTP effluent is primarily composed of ammonium, nitrite and nitrate, while nitrate accounts for more than 60\% [3]. WWTP effluent always has low organic content and low carbon-to-nitrogen ratio $(\mathrm{C} / \mathrm{N})$, and it perhaps contains lead and zinc ions caused by the dissolution of minerals $[4,5]$, which results in the complexity of WWTP effluent denitrification and nitrogen removal. 
It is difficult to achieve advanced nitrogen removal for WWTP effluent by traditional activated sludge processes. Some methods such as filtration and adsorption have been used for nutrient removal, which are often costly and difficult to maintain [6,7].

Moving bed biofilm reactors (MBBRs), which were developed in the 1980s for nitrogen removal, combine the advantages of activated sludge and biofilm in one reactor by dosing suspended carriers $[8,9]$. Biofilms, which attach and grow on the engineered carriers kept in constant suspension, are protected from abrasion when localized in the interior spaces of the MBBR carriers [10], and thus provide large surface area for the microbial colonization. Recent studies recommend MBBRs as promising alternative to the activated sludge systems with respect to the degradation of micropollutants [11-14]. MBBRs have been successfully employed to treat the municipal and industrial wastewater and upgrade small WWTPs $[15,16]$. Denitrifying MBBRs have been applied in the treatment of nitrate-contaminated wastewater as seawater, sewage, WWTP effluent, etc. [17-20], and good nitrate removal efficiency has been achieved. It has been reported that denitrifying MBBR filled with $30 \%$ polyethylene (PE) carrier obtained $61.9 \pm 16.8 \% \mathrm{TN}$ removal for the advanced WWPT effluent treatment, and the effluent $\mathrm{TN}$ concentration was less than $5 \mathrm{mg} / \mathrm{L}$ when the influent $\mathrm{COD}_{\text {added }} / \mathrm{NO}_{3}{ }^{-} \mathrm{-N}$ was kept at 4.6 by methanol addition as an external carbon source [21]. Liu et al. found that $25^{\circ} \mathrm{C}$ was the optimum temperature for the removal of nitrogen from WWTP effluent by denitrifying MBBR, considering the nitrogen and organic removal efficiency as a whole [22]. Li et al. used raw Arundo donax pieces as carbon source and biofilm carrier in a lab-scale denitrifying MBBR to remove $\mathrm{NO}_{3}{ }^{-}-\mathrm{N}$ from reverse osmosis concentrate, with high denitrification capability $\left(73.2 \% \pm 19.5 \% \mathrm{NO}_{3}{ }^{-}-\mathrm{N}\right.$ removal efficiency and $8.10 \pm 3.45 \mathrm{~g} \mathrm{NO}_{3}{ }^{-}-\mathrm{N} / \mathrm{m}^{3} / \mathrm{d}$ volumetric removal rate) obtained at stable operation stage [23].

In MBBR systems, the type and quantity of carriers directly affect the population distribution characteristics of microorganisms, and thus influence the wastewater treatment efficiency [20]. Quite some studies about MBBR carriers have been performed in recent years [24-26], and the carriers include granular activated carbon, sand, diatomaceous earth, polyethylene (PE), polyurethane foam (PUF) and several biodegradable materials [27,28]. PE carriers, which possess high porosity, are ideal microbial carriers for their microbial self-immobilization promotion, excellent mechanical strength and low-cost. Thus, they have been widely applied in various MBBRs, and achieved good pollutant removal efficiency for the treatment of different kinds of wastewater [29-31]. Four different carriers$\mathrm{PE}$, polypropylene (PP), PUF and haydite were investigated for their influence on the nitrogen removal efficiency of WWTP effluent treatment by denitrifying MBBR, and PE carriers were found to be the best type [20]. Moreover, some studies proved the feasibility and superiority of PE carriers in MBBR systems from various aspects $[30,31]$.

There are many factors affecting the MBBR performance on sewage treatment, and the most critical one is the surface area available for biofilm growth, which is related to the mechanical characteristics and filling ratio (FR) of the carriers [32]. Gu et al. [33] demonstrated that the FR of PE carriers significantly affected the chemical oxygen demand (COD), phenol, isothiocyanate and total ammonium removal in coking wastewater treatment by MBBR systems. Barwal and Chaudhary [34] showed that the MBBR with $40 \%$ FR of PP carrier exhibited excellent performance for synthetic municipal wastewater treatment. The aerobic MBBR with 30\% FR of sponge carrier achieved higher TN removal than those with $10 \%$ and $20 \%$ FRs [35]. Yuan et al. [36] reported that $96.3 \%$ ammonium removal efficiency was obtained by an aerobic MBBR with $40 \%$ FR of PUF carrier at 5 h hydraulic retention time (HRT), which was significantly higher than that achieved at 20\% FR (37.4\%). Additionally, 20\% 30\% FR was recommended by Deng et al. [24] and Piculell et al. [37] in their MBBR systems.

As mentioned above, quite some studies about the influence of FR on aerobic MBBRs have been carried out. However, the mechanisms of the FR effect on nitrogen removal and microbial characteristics for the denitrifying MBBR treatment of WWTP effluent have not been extensively investigated yet, and this study aimed to explore such mechanisms. A bench-scale denitrifying MBBR was constructed and operated at $20 \%, 30 \%, 40 \%$, and $50 \%$ carrier FRs, the relationship between the contaminant removal and FR was explored, and the diversity of microbial communities in the biofilms was analyzed by 
quantitative polymerase chain reaction (qPCR) and terminal restriction fragment length polymorphism (T-RFLP) methods. Moreover, the optimal carrier FR for denitrifying MBBR was recommended. The objective of this study was to provide theoretical basis for the advanced treatment of WWTP effluent by denitrifying MBBR.

\section{Materials and Methods}

\subsection{Experimental Denitrifying MBBR and Carrier}

A bench-scale denitrifying MBBR was assembled, which consisted of a plexiglass cylinder with $120 \mathrm{~mm}$ inner diameter, $500 \mathrm{~mm}$ height and $0.38 \mathrm{~L}$ tapered bottom (Figure 1). The total reactor volume was $6.03 \mathrm{~L}$, and the effective volume was $5.65 \mathrm{~L}$. The PE carriers were cylindrically shaped with $25 \mathrm{~mm}$ nominal diameter, $10 \mathrm{~mm}$ average length, $960-980 \mathrm{~kg} / \mathrm{m}^{3}$ specific density and $620 \mathrm{~m}^{2} / \mathrm{m}^{3}$ specific surface area (Dalian Yudu Environmental Engineering Technology Co., Ltd., Dalian, China).

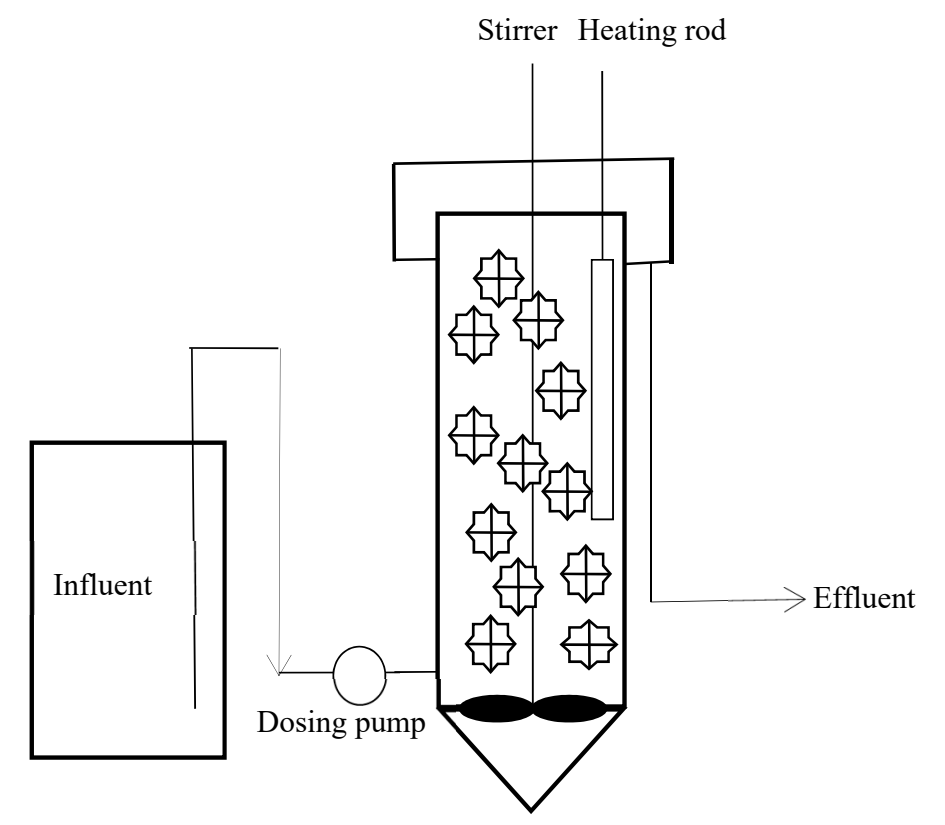

Figure 1. Schematic diagram of the laboratory denitrifying MBBR set-up.

\subsection{WWTP Effluent Characteristics and Experimental Design}

The effluent from Beijing Yongfeng WWTP, which uses Carrousel 3000 oxidation ditch treatment process, was supplied as denitrifying MBBR influent with $\mathrm{COD}_{\text {added }} / \mathrm{NO}_{3}{ }^{-}{ }^{-} \mathrm{N}$ maintained at 6.7 by methanol addition. Yongfeng WWTP with $20,000 \mathrm{~m}^{3} / \mathrm{d}$ designed treatment capacity, which was built in December 2008 and affiliated to Beijing Bihai Environmental Technology Co., Ltd., is located in Haidian District, Beijing, China. The influent, whose characteristics are listed in Table 1, was continuously fed to the reactor by peristaltic pump (BT100-1L, Baoding Lange Constant Pump Company, Beijing, China). The reactor was inoculated by the activated sludge taken from the anoxic tank of Beijing Yongfeng WWTP, and the inoculation mixed liquid suspended solids (MLSS), mixed liquor volatile suspended solids (MLVSS), MLVSS/MLSS, settling velocity (SV), and sludge volume index (SVI) were $7000 \mathrm{mg} / \mathrm{L}$, $3549 \mathrm{mg} / \mathrm{L}, 0.51,66 \%$, and $94 \mathrm{~mL} / \mathrm{g}$, respectively. At the beginning of the experiment, $2 \mathrm{~L}$ activated sludge was dosed with $4 \mathrm{~L}$ WWTP effluent in the reactor. Then, low flow rate was applied, which gradually increased to the scheduled HRT. The experiment was operated at four phases with different FRs, i.e., 20\% (Phase I), 30\% (Phase II), 40\% (Phase III), and 50\% (Phase IV). A heating rod was used to maintain the water temperature at $24-26^{\circ} \mathrm{C}$, while a propeller stirrer with $80 \mathrm{~mm}$ diameter and $30 \mathrm{rpm}$ speed was used to mix the sludge, carrier and wastewater. The HRT of each phase was $12 \mathrm{~h}$. 
The treatment performance was evaluated by the influent and effluent $\mathrm{NO}_{3}{ }^{-}-\mathrm{N}, \mathrm{NO}_{2}{ }^{-}-\mathrm{N}, \mathrm{NH}_{4}{ }^{+}-\mathrm{N}$, $\mathrm{TN}$, and COD analysis once every two days.

Table 1. Water quality of the WWTP effluent used as influent.

\begin{tabular}{cccccccc}
\hline Phase & $\begin{array}{c}\text { Operational } \\
\text { Day }(\mathbf{d})\end{array}$ & $\mathbf{p H}$ & $\begin{array}{c}\mathrm{NO}_{3}-\mathbf{N} \\
(\mathbf{m g} / \mathbf{L})\end{array}$ & $\begin{array}{c}\mathbf{N O}_{\mathbf{2}}-\mathbf{N} \\
(\mathbf{m g} / \mathbf{L})\end{array}$ & $\begin{array}{c}\mathbf{N H}_{4}{ }^{+}-\mathbf{N} \\
(\mathbf{m g} / \mathbf{L})\end{array}$ & $\mathbf{T N}(\mathbf{m g} / \mathbf{L})$ & $\begin{array}{c}\mathrm{COD}^{*} \\
(\mathbf{m g} / \mathbf{L})\end{array}$ \\
\hline I & $0-30$ & $7.2-7.9$ & $4.7 \pm 2.6$ & $0.6 \pm 0.2$ & $0.7 \pm 0.2$ & $8.7 \pm 5.2$ & $52.2 \pm 25.3$ \\
II & $31-50$ & $7.1-7.8$ & $6.4 \pm 2.5$ & $0.8 \pm 0.4$ & $1.4 \pm 0.5$ & $11.0 \pm 3.0$ & $68.9 \pm 9.0$ \\
III & $51-70$ & $7.1-7.8$ & $6.4 \pm 2.5$ & $0.8 \pm 0.4$ & $1.4 \pm 0.5$ & $11.0 \pm 3.0$ & $68.9 \pm 9.0$ \\
IV & $71-90$ & $7.2-7.9$ & $5.1 \pm 2.4$ & $0.7 \pm 0.2$ & $0.9 \pm 0.6$ & $8.9 \pm 4.8$ & $52.2 \pm 25.3$ \\
\hline \multicolumn{7}{c}{${ }^{*}$ COD is the corresponding value of 6.7 $\mathrm{COD}_{\text {added }} / \mathrm{NO}_{3}{ }^{--} \mathrm{N}$ achieved by methanol addition. }
\end{tabular}

\subsection{Sample Collection and Analysis}

Water samples were collected from the inlet and outlet of the system during each operation phase and analyzed immediately at the Laboratory of Chinese Research Academy of Environmental Sciences. $\mathrm{COD}$ and $\mathrm{NH}_{4}{ }^{+}-\mathrm{N}$ were analyzed according to the standard methods [38]. TN was measured by TOC- $\mathrm{V}_{\mathrm{CPH}}$ total organic carbon (TOC) analyzer (Shimadzu, Kyoto, Japan), while $\mathrm{NO}_{2}{ }^{-}-\mathrm{N}$ and $\mathrm{NO}_{3}{ }^{-}-\mathrm{N}$ were determined by ion chromatography (ICS-1000, DIONEX, California, USA). All samples for TN, $\mathrm{NO}_{2}{ }^{-}-\mathrm{N}, \mathrm{NO}_{3}{ }^{-}-\mathrm{N}$, and $\mathrm{NH}_{4}{ }^{+}-\mathrm{N}$ measurement were pretreated by $0.45 \mu \mathrm{m}$ membrane filter.

\subsection{Biofilm Characteristics}

Biofilms on carriers of different phases at stable operation stage were compared using different techniques to characterize their physical features, microbial population dynamics and distribution.

\subsubsection{Biomass}

The biomass of the carrier biofilm was determined as follows: A certain amount of carriers were taken from the reactor, submerged in $20 \mathrm{~mL} \mathrm{NaOH}$ of $1 \mathrm{M}$ in a clean tube, maintained at $80^{\circ} \mathrm{C}$ for $30 \mathrm{~min}$ in water bath, ultrasonically treated for $1 \mathrm{~min}$ at $100 \mathrm{~W}$ to separate the fixed bacteria from the carrier surface, vortexed for $30 \mathrm{~s}$ to uniformly disperse the bacteria in solution [39], and then the dry weight of the biofilm was measured.

\subsubsection{Scanning Electron Microscopy (SEM)}

The microbe distribution on the carrier surface was analyzed using SEM. An appropriate amount of biofilm-attached carriers were obtained from the denitrifying MBBR at stable stage. Approximately $5 \times 5 \mathrm{~mm}$ biofilm-containing samples were cut from the obtained carriers, then fixed by $2.5 \%$ neutral glutaraldehyde and washed with phosphate buffer. Following ethanol gradient dehydration, the samples underwent critical point drying in $\mathrm{CO}_{2}$ critical point dryer (SPI Inc., PA, California, USA) and ion-sputtered with gold in Eiko Ion Coater (model IB-3, Hatachi Inc., Naka, Japan), and then their morphology was observed by SEM (HITACHI S-570 SEM, Hatachi Inc., Naka, Japan) at an accelerating voltage of $12 \mathrm{kV}$.

\subsection{3. qPCR and T-RFLP Analysis}

About $2 \mathrm{~g}$ wet biofilm abraded from the denitrifying MBBR carriers at stable operation stage was put into the sterile Eppendorf tube. Genomic DNA, which was extracted from the biofilm samples by UltraClean DNA Kit (Mobio Laboratories, California, USA) according to the protocol provided by the manufacturer, was detected by $1 \%$ agarose gel electrophoresis and stored at $-20^{\circ} \mathrm{C}$ for future use. Nitrous oxide reductase (nosZ) primers as nosZ-F (5'-CGYTGTTCMTCGACAGCCAG-3' with the 5 '-end labeled with carboxyfluorescein) and nosZ1622R (5'-CGSACCTTSTTGCCSTYGCG-3) [40] were used for DNA amplification. The PCR amplification conditions were as follows: 1 cycle at $94{ }^{\circ} \mathrm{C}$ 
for $5 \mathrm{~min}, 35 \mathrm{cycles}$ at $95{ }^{\circ} \mathrm{C}$ for $0.5 \mathrm{~min}, 55^{\circ} \mathrm{C}$ for $0.5 \mathrm{~min}$ and $72{ }^{\circ} \mathrm{C}$ for $1.5 \mathrm{~min}$, final extension at $72{ }^{\circ} \mathrm{C}$ for $10 \mathrm{~min}$ [41]. Restriction enzyme (HhaI) was used to digest the PCR products purified with QIAquick PCR purification kit (Qiagen Inc, Berlin, Germany) at $37^{\circ} \mathrm{C}$ for $3 \mathrm{~h}$. The Shannon-Wiener index and Bray-Curtis similarity index, which are based on the concept of evenness or equitability, were calculated $[42,43]$ to evaluate the bacterial species diversity and similarity among different samples. qPCR was conducted as follows: The nitrate reductase (nar $G$ ) and nos $Z$ genes were amplified by PCR, ligated into the pMD-19T vector, and transformed; the plasmid was extracted; the positive clones were identified with PCR, and then sequenced and identified (Beijing Nosy Genome Research Center, Ltd.).

\section{Results and Discussion}

\subsection{Effects of FR on COD removal}

At FRs of $20 \%, 30 \%, 40 \%$, and $50 \%$, the average COD removal rates were $33.8 \pm 18.4 \%, 37.7 \pm 17.1 \%$, $47.0 \pm 15.5 \%$, and $55.2 \pm 11.8 \%$, respectively. The COD removal efficiency increased with the increase of FR, and all the effluent COD met the Class I(A) requirement of the Discharge Standard of Pollutants for Municipal WWTP in China (GB18918-2002) [1], i.e., less than $50 \mathrm{mg} \mathrm{L}^{-1}$. The above-mentioned effluent COD value was consistent with that of the denitrifying MBBR for WWPT effluent treatment [21].

\subsection{Effects of FR on Nitrogen Removal}

\subsubsection{Effects of FR on Ammonium, Nitrite Conversion and TN Removal}

As shown in Table 2, the $\mathrm{NH}_{4}{ }^{+}-\mathrm{N}$ removal rates at $30 \%$ and $40 \%$ FRs were higher than those at $20 \%$ and $50 \%$ FRs. However, since low influent nitrogen load is more conducive to TN removal in biofilm systems [44], lower TN removal rates were observed at 30\% and $40 \%$ FRs. Slight $\mathrm{NO}_{2}{ }^{-}-\mathrm{N}$ accumulation occurred in the reactor, which might have resulted from the activity inhibition of the nitrifying bacteria caused by limited dissolved oxygen. Another possible explanation for this phenomenon was that the microbe could not easily metabolize methanol, which thus led to insufficient available carbon in the system. Then, the carbon deficiency caused incomplete denitrification, in which nitrate was reduced to nitrite instead of nitrogen, and resulted in nitrite accumulation [45].

When appropriate FR was applied, the biofilms attached to the carriers would exist for long HRTs, which ensured the growth of autotrophic nitrifying microorganisms on the biofilms with long generation period and slow proliferation rate. The large gaps between the carriers promoted adequate contact among the solid, gas and liquid materials, which increased the mass transfer area and rate and then resulted in enhanced growth of the microorganisms [46]. As illustrated in Table 2, the turbulent conditions might be worsened when the FR is greater than $50 \%$, and a large number of microorganisms might be stripped from the carrier surface due to the effects of mass transfer and hydraulic shearing, thus impeding the growth of the bacteria related with $\mathrm{NH}_{4}{ }^{+}-\mathrm{N}$ removal. $\mathrm{Li}$ et al. reported that the anammox gene existed in the carrier biofilm of denitrifying MBBR for reverse osmosis concentrate treatment [23]. The weakening of the anammox gene bacteria is bound to reduce the $\mathrm{NH}_{4}{ }^{+}-\mathrm{N}$ removal efficiency of the whole system. The $\mathrm{NH}_{4}{ }^{+}-\mathrm{N}$ removal efficiency trend observed in this study could be explained by the reasons mentioned above.

As a result, 30\% and 40\% FRs are recommended as the optimal FRs for denitrifying MBBR based on ammonium, nitrite conversion and TN removal. 
Table 2. $\mathrm{NH}_{4}{ }^{+}-\mathrm{N}, \mathrm{NO}_{2}{ }^{-}-\mathrm{N}$, and $\mathrm{TN}$ removal efficiency and biofilm mass of denitrifying MBBR at different FRs.

\begin{tabular}{|c|c|c|c|c|c|c|c|c|c|c|}
\hline \multirow{2}{*}{ FR(\%) } & \multicolumn{3}{|c|}{$\mathrm{NH}_{4}{ }^{+}-\mathrm{N}(\mathrm{mg} / \mathrm{L})$} & \multicolumn{3}{|c|}{$\mathrm{NO}_{2}-\mathrm{N}(\mathrm{mg} / \mathrm{L})$} & \multicolumn{3}{|c|}{ TN (mg/L) } & \multirow[t]{2}{*}{$\begin{array}{l}\text { Biofilm mass } \\
\text { (mg/g-carriers) }\end{array}$} \\
\hline & Influent & Effluent & $\begin{array}{c}\text { Removal } \\
\text { rate }(\%)\end{array}$ & Influent & Effluent & $\begin{array}{c}\text { Removal } \\
\text { rate }(\%)\end{array}$ & Influent & Effluent & $\begin{array}{c}\text { Removal } \\
\text { rate }(\%)\end{array}$ & \\
\hline 20 & $0.7 \pm 0.2$ & $0.5 \pm 0.3$ & $27.9 \pm 39.1$ & $0.6 \pm 0.2$ & $0.8 \pm 0.5$ & $\begin{array}{c}-21.1 \pm \\
61.9\end{array}$ & $8.7 \pm 5.2$ & $2.6 \pm 3.2$ & $74.5 \pm 16.0$ & 4.86 \\
\hline 30 & $1.4 \pm 0.5$ & $0.8 \pm 0.4$ & $38.5 \pm 28.0$ & $0.8 \pm 0.4$ & $0.9 \pm 0.4$ & $\begin{array}{c}-29.6 \pm \\
65.7\end{array}$ & $\begin{array}{c}11.0 \pm \\
3.0\end{array}$ & $6.2 \pm 2.2$ & $42.1 \pm 16.2$ & 3.29 \\
\hline 50 & $0.9 \pm 0.6$ & $0.6 \pm 0.2$ & $19.4 \pm 39.6$ & $0.7 \pm 0.2$ & $0.7 \pm 0.3$ & $-4.9 \pm 26.7$ & $8.9 \pm 4.8$ & $1.9 \pm 2.0$ & $80.4 \pm 11.4$ & 2.17 \\
\hline
\end{tabular}

\subsubsection{Effects of FR on Nitrate Removal}

Figure 2 presents the $\mathrm{NO}_{3}{ }^{-}-\mathrm{N}$ removal capability at different FRs during the entire denitrifying MBBR operation period. The $\mathrm{NO}_{3}{ }^{-}-\mathrm{N}$ removal rates were $94.3 \pm 3.9 \%, 87.7 \pm 7.3 \%, 89.7 \pm 11.6 \%$, and $94.6 \pm 4.0 \%$ at FRs of $20 \%, 30 \%, 40 \%$, and $50 \%$, while the effluent $\mathrm{NO}_{3}{ }^{-}-\mathrm{N}$ concentration was $0.2 \pm 0.1 \mathrm{mg} / \mathrm{L}, 0.8 \pm 0.5 \mathrm{mg} / \mathrm{L}, 0.6 \pm 0.5 \mathrm{mg} / \mathrm{L}$, and $0.2 \pm 0.1 \mathrm{mg} / \mathrm{L}$, respectively. The denitrification rate $\left(\mathrm{r}_{\mathrm{NO} 3-\mathrm{N}}\right)$ was obtained using linear regression of the $\mathrm{NO}_{3}{ }^{-}-\mathrm{N}$ concentration measured during the experiments. As shown in Figure 2, the denitrification rates at FRs of 20\%, 30\%, 40\%, and 50\% were $8.0 \pm 5.6,11.3 \pm 4.6,11.6 \pm 4.6$, and $10.0 \pm 4.9 \mathrm{mgNO}_{3}{ }^{-}-\mathrm{N} / \mathrm{L} / \mathrm{d}$, and higher denitrification rates were obtained at $30 \%$ and $40 \%$ FRs. The denitrification rate, which was closely related to the influent $\mathrm{NO}_{3}{ }^{-}-\mathrm{N}$ concentration, increased with the increase of influent $\mathrm{NO}_{3}{ }^{-}-\mathrm{N}$ [19].

Denitrifying bacteria are facultative heterotrophic microorganisms that grow rapidly and proliferate within a short period of time. In denitrifying MBBR systems, denitrifying bacteria need organic matter to act as electron donors for nitrate conversion. Therefore, the microorganism population increase in the system might lead to the decrease of microbial activity for the scarcity of carbon source. The denitrification rate increased with the increase of influent nitrate load, which might have been caused by the enhancement of denitrifying bacteria activity, and such results indicated that the system has great potential for the treatment of wastewater with high nitrate concentration. It is reported that a woodchip bioreactor with high $\mathrm{NO}_{3}{ }^{-}-\mathrm{N}$ load increased the denitrification rate in similar systems, which is consistent with the results of this study [47].

Therefore, FRs of $30 \%$ and $40 \%$ are recommended as the optimal ones for denitrifying MBBR in the aspect of nitrate removal.
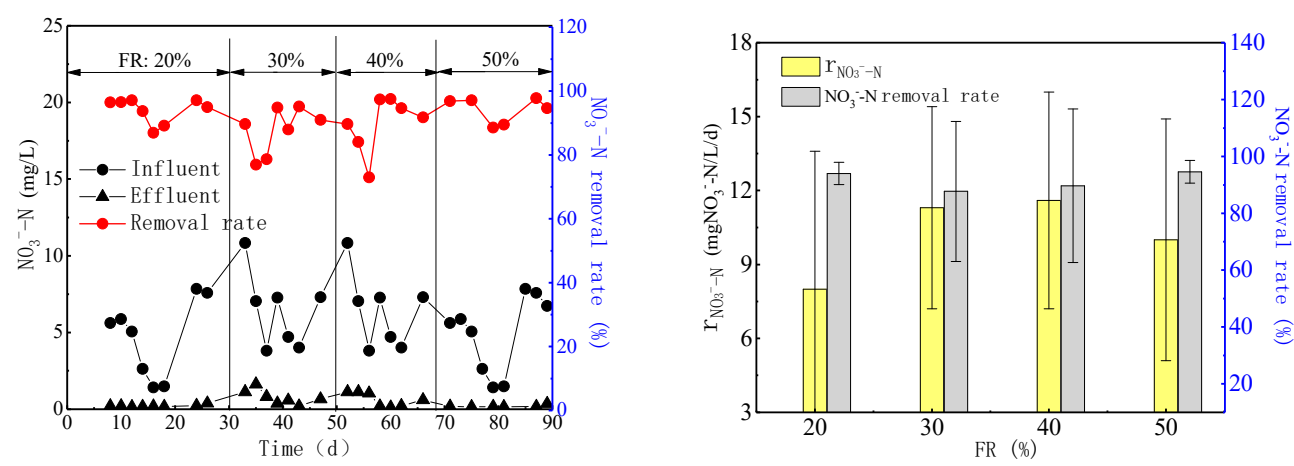

Figure 2. $\mathrm{NO}_{3}{ }^{-}-\mathrm{N}$ removal rate and denitrification rate $\left(\mathrm{r}_{\mathrm{NO}-\mathrm{N}}\right)$ at different FRs.

\subsection{Effects of FR on Microbial Community}

\subsubsection{Effects of FR on Biomass}

As shown in Table 2, the amount of microorganisms on carriers at $20 \%$ FR ( $4.86 \mathrm{mg} / \mathrm{g}$ carriers) was the largest, compared with those at 30\%, 40\%, and 50\% FRs (3.29 mg/g carriers, $2.51 \mathrm{mg} / \mathrm{g}$ carriers, 
and $2.17 \mathrm{mg} / \mathrm{g}$ carriers, respectively), which might have resulted from the lower hydraulic shearing effect and the relatively stable growth environment for the microorganisms. However, the mass transfer between microorganisms and nutrients was hindered at $20 \% \mathrm{FR}$, which might lead to relatively low biofilm activity [48]. Moreover, lower total microorganism population was observed because of the smaller total surface area of the carriers available for microbial attachment. The ratio of the biofilm to the unit weight of carrier decreased with the increase of FR, but the total biofilm mass of the entire system increased correspondingly due to the greater number and larger support surface of the carriers [35]. The biofilm thickness on each carrier decreased with the increase of FR, which facilitated the mass exchange and biofilm renewal in the denitrifying MBBR and resulted in higher vitality [48] and denitrification rate of the microorganisms (Figure 2). However, if the FR was too high (greater than 50\%), the anoxic zone on the carrier surface would reduce due to the thinner biofilm, which would increase the aerobic microorganisms and then cause its carbon competition with the denitrifying bacteria. Aerobic microorganisms consume large amounts of organic matters in the water, which decreases the denitrification rate of the denitrifying bacteria for insufficient electron donors [49]. The theories mentioned above could explain the increase of COD removal rate and the decrease of denitrification rate at high FR conditions in this study.

\subsubsection{Effects of FR on Biofilm Thickness and Appearance}

In general, the biofilms attach to the carriers in two different forms, i.e., thick and dense biofilm developed on the carrier surface, and biofilm deposited or entrapped in the interior voids of the carriers [36]. It can be seen from the SEM micrographs of the PE carrier obtained after acclimatization that thick and dense biofilms had formed. As shown in Figure 3, the biofilms were primarily composed of cocci, bacillus, filamentous bacteria and extracellular polymeric substances (EPS) under all experimental FR conditions, while cocci and bacillus accounted for the majority. Bacilli, cocci, and EPS assembled together, formed zoogloea and adhered to the carrier surface. At $20 \%$ FR, quite some viscous substances, cocci and bacillus presented together on the biofilms, formed compact microbial structure. The filamentous bacteria population increased and the biofilm thickness decreased with the increase of FR, which led to looser microbial structure, and similar results were observed in other studies [48]. Moreover, SEM was used to determine the biofilm composition on the carrier surface, which discovered that the biofilms in the denitrification system were primarily composed of rod bacteria and cocci [20], and rod bacteria were the predominant species in the denitrifying packed bed bioreactors [50]. The bacteria morphology of this study is similar with that of the reports mentioned above.

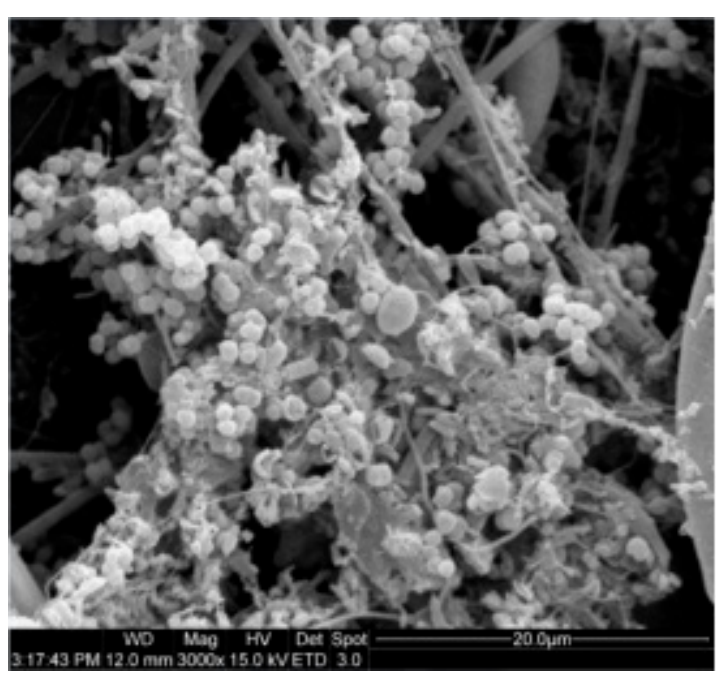

(a)

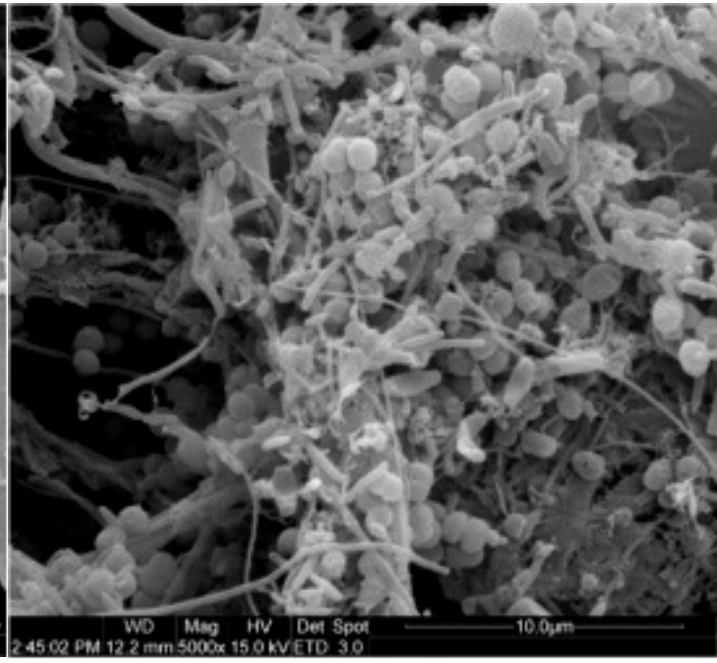

(b)

Figure 3. Cont. 


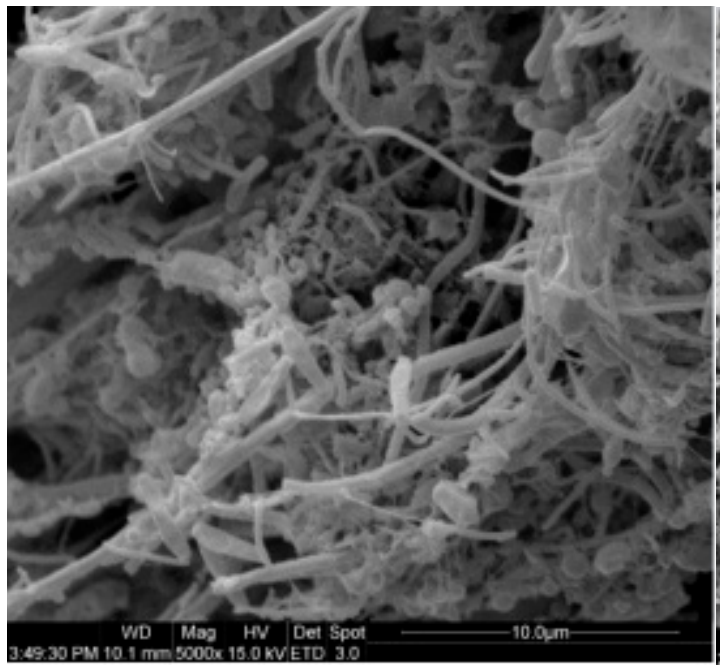

(c)

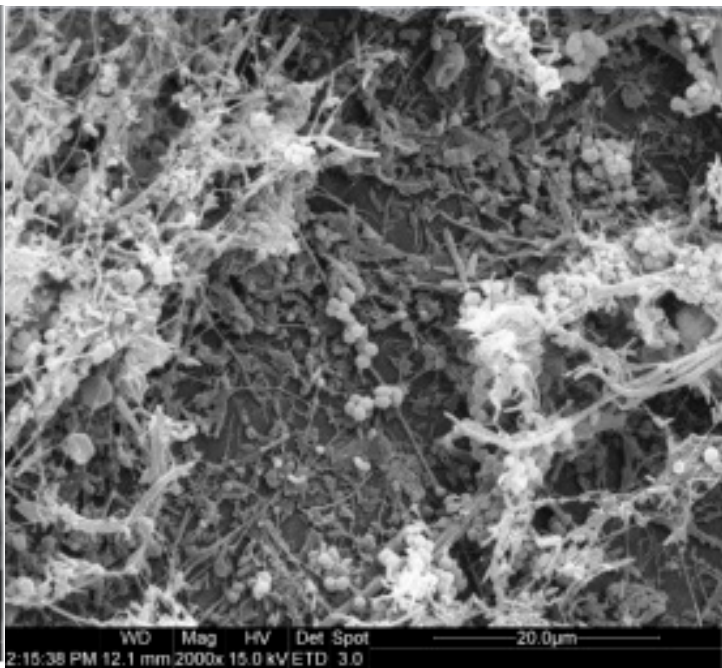

(d)

Figure 3. SEM micrographs of the biofilm at different FRs: (a) $20 \%$, (b) $30 \%$, (c) $40 \%$ and (d) $50 \%$.

\subsubsection{Effects of FR on Microbial Abundance}

Denitrification requires the synergy of multiple microorganisms and enzymes (Figure 4). nos Z and nar $G$ are the key genes needed for the conversion of nitrous oxide to nitrogen during the microbial denitrification process [51], and the abundance variation of these two genes can reflect the denitrification capacity [52]. In this study, qPCR based on nosZ and nar G genes were used to evaluate the nitrogen removal capacity, which is presented in Table 3. Both the nos $Z$ and nar G gene abundance, which were increased with the increase of FR, were remarkably lower at 20\% FR than those at other FRs, and they were within an order of magnitude at FRs of $30 \%, 40 \%$ and $50 \%$. These results demonstrated that the increase of FR could not significantly improve the abundance of denitrifying bacteria genes when the FR was greater than $30 \%$, which was consistent with the variation trends of the denitrification rate.

Table 3. Distribution of denitrifying bacteria functional genes and Shannon-Wiener index with evenness at different FRs.

\begin{tabular}{ccccc}
\hline Filling rate & $\mathbf{2 0} \%$ & $\mathbf{3 0} \%$ & $\mathbf{4 0} \%$ & $\mathbf{5 0 \%}$ \\
\hline narG abundance (copies/g-SS) & $2.76 \times 10^{7}$ & $1.00 \times 10^{8}$ & $2.78 \times 10^{8}$ & $2.89 \times 10^{8}$ \\
nosZ abundance (copies/g-SS) & $7.66 \times 10^{4}$ & $1.74 \times 10^{7}$ & $2.15 \times 10^{7}$ & $2.42 \times 10^{7}$ \\
Shannon-Wiener index (H') & 0.4 & 1.9 & 1.3 & 1.6 \\
Evenness (E') & 0.6 & 0.9 & 0.9 & 1.0 \\
\hline
\end{tabular}

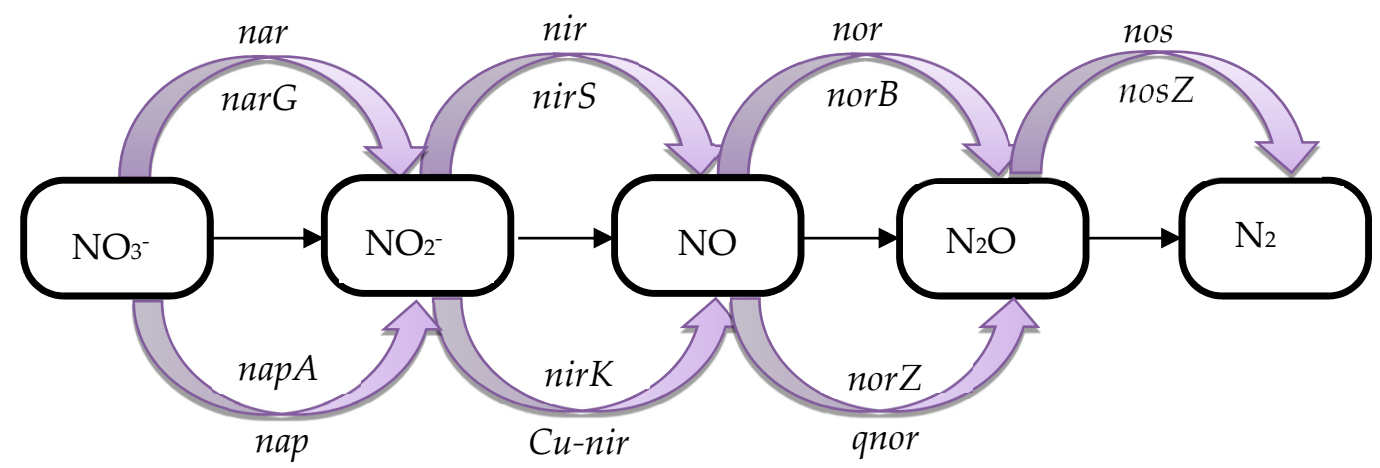

Figure 4. nosZ community structure at different FRs. 


\subsubsection{Effects of FR on Microbial Community Diversity}

T-RFLP, which is a culture-independent molecular genetic method for generating profiles or fingerprints of environmental microbial communities [53,54], is a common tool in the characterization of microbes. In this study, nosZ-based T-RFLP was used to examine the influence of FR on the community diversity of denitrifying microbes. HhaI digestion of the PCR products illustrated the distribution of the resulting terminal restriction fragment (TRF) peaks, whose numbers and relative abundance varied among the profiles, and the results indicated that the sampled bacterial communities differed in their diversity and species composition (Figure 5). The predominant fragment observed at $20 \%$, $30 \%$, and $40 \%$ FRs was $168 \mathrm{bp}$ (HhaI), which accounted for $84.7 \%, 32.4 \%$, and $47.8 \%$, respectively. The predominant fragment observed at 50\% FR was of 31.5\% relative abundance with $250 \mathrm{bp}$. The $168 \mathrm{bp}$ and $250 \mathrm{bp}$ fragments might represent the primary denitrifying bacteria in the denitrifying MBBR. The Shannon-Wiener index $\left(\mathrm{H}^{\prime}\right)$ and evenness $\left(\mathrm{E}^{\prime}\right)$ at different FRs are presented in Table 3. The functional diversity of the biofilm microbial community at 30\% FR was higher than that at $20 \%, 40 \%$, and $50 \%$ FRs. At $30 \%$ FR, the evenness, which increased with the increase of FR, was significantly higher than that at $20 \%$ FR. However, the evenness variation was not obvious when the FR was greater than $30 \%$, and the highest evenness was achieved at $50 \%$ FR, which was consistent with other reports about the MBBR systems [9].

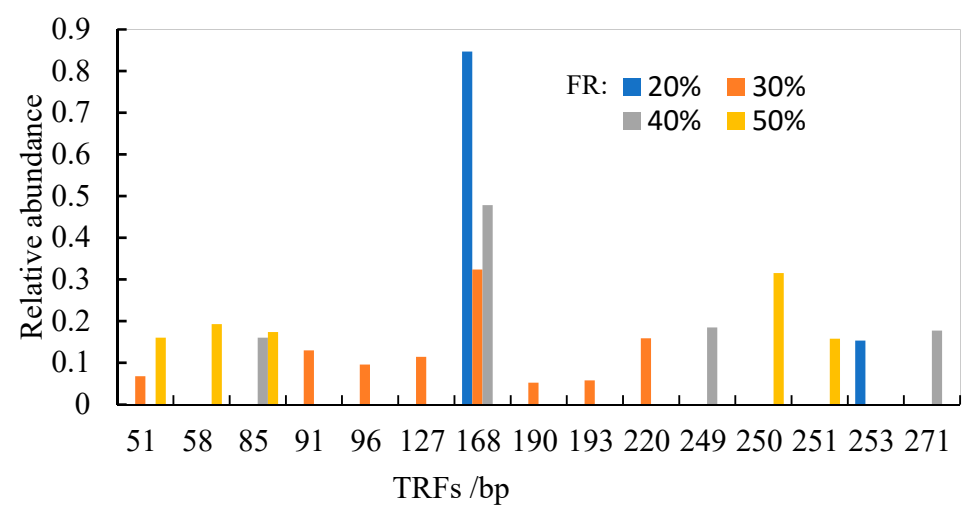

Figure 5. nosZ-based community structure at different FRs.

\subsection{Analysis about the Application to Other Scale Reactors}

Overall, 30\% and 40\% are recommended as the optimal FRs for denitrifying MBBR based on the ammonium and nitrite conversion, TN and nitrate removal. The microbial community diversity, evenness and denitrifying bacteria functional gene abundance (nos $Z$ and $\operatorname{nar} G$ ) of the biofilms at $30 \%$ FR were significantly higher than those at $20 \%$ FR, while no significant differences were observed at $30 \%, 40 \%$, and $50 \%$ FRs. Therefore, $30 \%$ is recommended as the optimum FR for denitrifying MBBR, which provides theoretical support for the construction and operation of the pilot-scale and full-scale denitrifying MBBR for the treatment of WWTP effluent as recharge water for rivers or groundwater.

\section{Conclusions}

The FR influence of the PE carrier on the performance and microbial characteristics of denitrifying MBBR for the treatment of WWTP effluent was extensively investigated by a bench-scale reactor at $12 \mathrm{~h} \mathrm{HRT}, 6.7 \mathrm{COD}$ added $/ \mathrm{NO}_{3}{ }^{-}-\mathrm{N}$ and $24-26^{\circ} \mathrm{C}$ temperature, and the conclusions were as follows:

(1) Excellent performance in terms of COD and nitrogen removal was achieved using PE carriers at FRs of $20 \%, 30 \%, 40 \%$, and $50 \%$. The $\mathrm{NO}_{3}{ }^{-}-\mathrm{N}$ removal efficiency and denitrification rates at $20 \%$, $30 \%, 40 \%$, and $50 \%$ FRs were $94.3 \pm 3.9 \%$ and $8.0 \pm 5.6 \mathrm{mg} \mathrm{NO}_{3}{ }^{-}-\mathrm{N} / \mathrm{L} / \mathrm{d}, 87.7 \pm 7.3 \%$ and $8.0 \pm 5.6 \mathrm{mg}$ $\mathrm{NO}_{3}{ }^{-}-\mathrm{N} / \mathrm{L} / \mathrm{d}, 89.7 \pm 11.6 \%$ and $8.0 \pm 5.6 \mathrm{mg} \mathrm{NO}_{3}{ }^{-}-\mathrm{N} / \mathrm{L} / \mathrm{d}$, and $94.6 \pm 4.0 \%$ and $10.0 \pm 4.9 \mathrm{mg} \mathrm{NO}{ }^{-}$ $-\mathrm{N} / \mathrm{L} / \mathrm{d}$, respectively. No remarkable changes were observed for $\mathrm{NO}_{3}{ }^{-}-\mathrm{N}$ removal efficiency at different FRs, but higher denitrification rates were obtained at $30 \%$ and $40 \%$ FRs. 
(2) The biomass of the carrier biofilm decreased with the increase of FR, but the total biofilm biomass of the entire system increased due to the greater number of carriers. The SEM results demonstrated that the biofilms were primarily composed of cocci, bacillus, filamentous bacteria and EPS at all FRs, while cocci and bacillus accounted for the majority. The filamentous bacteria population increased and the biofilm thickness decreased with the increase of FR.

(3) The microbial community diversity, evenness, and denitrifying bacteria functional gene abundance (nosZ and narG) of the biofilms at 30\% FR were significantly higher than those at $20 \%$ FR, and no significant differences were observed at $30 \%, 40 \%$, and $50 \%$ FRs.

(4) Overall, $30 \%$ is recommended as the optimum FR for denitrifying MBBR, which provides theoretical support for the construction and operation of the pilot-scale and full-scale denitrifying MBBR for the treatment of WWTP effluent as recharge water for rivers or groundwater.

Author Contributions: Y.Z., Q.Y., and Z.H. conceived and conducted the experiments, as well as sampling and monitoring while H.W. supervised. Y.Z., Y.L. and H.W. drafted the paper. G.Y., Y.C. and Z.C. provided critical revision of the manuscript. All of the authors read and approved the submitted manuscript.

Funding: This research was funded by the National Major Science and Technology Program for Water Pollution Control and Treatment (2017ZX07401003-05, 2015ZX07201-008, and 2014ZX07216-001).

Acknowledgments: This authors are grateful for the support of the National Major Science and Technology Program for Water Pollution Control and Treatment (2017ZX07401003-05, 2015ZX07201-008, and 2014ZX07216-001).

Conflicts of Interest: The authors declare no conflict of interest.

\section{References}

1. SEPA; AQSIQ. Discharge Standard of Pollutants for Municipal Wastewater Treatment Plant; Ministry of Ecology and Environment: Beijing, China, 2002.

2. SEPA; AQSIQ. Environmental Quality Standards for Surface Water; Ministry of Ecology and Environment: Beijing, China, 2002.

3. Liu, C.; Li, J.; Chen, W.; Chen, B.; Qiu, B. Treatment Efficiency of Secondary Effluent by Combined Process of Contact Filtration and Magnetic Ion Exchange Resin. China Water Wastewater 2011, 27, 13-15.

4. $\quad$ Feng, Q.; Wen, S.; Bai, X.; Chang, W.; Cui, C.; Zhao, W. Surface modification of smithsonite with ammonia to enhance the formation of sulfidization products and its response to flotation. Miner. Eng. 2019, 137, 1-9. [CrossRef]

5. Feng, Q.; Wen, S.; Deng, J.; Zhao, W. Combined DFT and XPS investigation of enhanced adsorption of sulfide species onto cerussite by surface modification with chloride. Appl. Surf. Sci. 2017, 425, 8-15. [CrossRef]

6. Bhamidimarri, R.; Shilton, A.; Armstrong, I.; Jacobson, P.; Scarlet, D. Constructed wetlands for wastewater treatment: The New Zealand experience. Water Sci. Technol. 1991, 24, 247-253. [CrossRef]

7. Horne, A.J. Nitrogen removal from waste treatment pond or activated sludge plant effluents with free surface wetlands. Water Sci. Technol. 1995, 31, 341-351. [CrossRef]

8. Ødegaard, H.; Mende, U.; Skjerping, E.O.; Simonsen, S.; Strube, R.; Bundgaard, E. Compact tertiary treatment based on the combination of MBBR and contained hollow fibre UF-membranes. Desalin. Water Treat. 2012, 42, 80-86. [CrossRef]

9. Rusten, B.; Eikebrokk, B.; Ulgenes, Y.; Lygren, E. Design and operations of the Kaldnes moving bed biofilm reactors. Aquac. Eng. 2006, 34, 322-331. [CrossRef]

10. Young, B.; Delatolla, R.; Kennedy, K.; Laflamme, E.; Stintzi, A. Low temperature MBBR nitrification: Microbiome analysis. Water Res. 2017, 111, 224-233. [CrossRef]

11. Casas, M.E.; Chhetri, R.K.; Ooi, G.; Hansen, K.M.S.; Litty, K.; Christensson, M.; Kragelund, C.; Andersen, H.R.; Kai, B. Biodegradation of pharmaceuticals in hospital wastewater by staged Moving Bed Biofilm Reactors (MBBR). Water Res. 2015, 83, 293-302. [CrossRef]

12. Falås, P.; Baillon-Dhumez, A.; Andersen, H.R.; Ledin, A.; Jansen, J.L.C. Suspended biofilm carrier and activated sludge removal of acidic pharmaceuticals. Water Res. 2012, 46, 1167-1175. [CrossRef]

13. Hapeshi, E.; Lambrianides, A.; Koutsoftas, P.; Kastanos, E.; Michael, C.; Fatta-Kassinos, D. Investigating the fate of iodinated X-ray contrast media iohexol and diatrizoate during microbial degradation in an MBBR system treating urban wastewater. Environ. Sci. Pollut. Res. 2013, 20, 3592-3606. [CrossRef] [PubMed] 
14. Torresi, E.; Fowler, S.J.; Polesel, F.; Bester, K.; Andersen, H.R.; Smets, B.F.; Plósz, B.G.; Christensson, M. Biofilm Thickness Influences Biodiversity in Nitrifying MBBRs-Implications on Micropollutant Removal. Environ. Sci. Technol. 2016, 50, 9279-9288. [CrossRef] [PubMed]

15. Abtahi, S.M.; Petermann, M.; Flambard, A.J.; Beaufort, S.; Terrisse, F.; Trotouin, T.; Cassan, C.J.; Albasi, C. Micropollutants removal in tertiary moving bed biofilm reactors (MBBRs): Contribution of the biofilm and suspended biomass. Sci. Total Environ. 2018, 643, 1464-1480. [CrossRef] [PubMed]

16. Chen, S.; Sun, D.; Chung, J.S. Treatment of pesticide wastewater by moving-bed biofilm reactor combined with Fenton-coagulation pretreatment. J. Hazard. Mater. 2007, 144, 577-584. [CrossRef] [PubMed]

17. DeBarbadillo, C.; Bates, J.; Chan, T.; Steichen, M.; Wallis-Lage, C. Experiences in Using MBBR and Denitrification Filters for Nitrogen Removal. Proc. Water Environ. Fed. 2010, 2010, 254-264. [CrossRef]

18. Rusten, B.; Hem, L.J.; Odegaard, H. Nitrogen removal from dilute wastewater in cold climate using moving-bed biofilm reactors. Water Environ. Res. 1995, 67, 65-74. [CrossRef]

19. Labelle, M.A.; Juteau, P.; Jolicoeur, M.; Villemur, R.; Parent, S.; Comeau, Y. Seawater denitrification in a closed mesocosm by a submerged moving bed biofilm reactor. Water Res. 2005, 39, 3409-3417. [CrossRef]

20. Yuan, Q.; Wang, H.; Hang, Q.; Deng, Y.; Liu, K.; Li, C.; Zheng, S. Comparison of the MBBR denitrification carriers for advanced nitrogen removal of wastewater treatment plant effluent. Environ. Sci. Pollut. Res. Int. 2015, 22, 13970. [CrossRef]

21. Yuan, Q.; Wang, H.C.; Zheng, S.; Hang, Q.; Liu, K.; Li, C. Influence of C/N Ratio on MBBR denitrification for advanced nitrogen removal of wastewater treatment plant effluent. Desalin. Water Treat. 2017, 66, 158-165. [CrossRef]

22. Liu, K.; Wang, H.Y.; Ma, M.J.; Zhang, C.; Yuan, Q.; Hang, Q.; Li, C. Influence of Temperature on Nitrogen Removal from Wastewater Treatment Plant Effluent by Denitrification MBBR. Res. Environ. Sci. 2016, 29, 877-886.

23. Li, L.; Yan, G.; Wang, H.; Chu, Z.; Li, Z.; Ling, Y.; Wu, T. Denitrification and microbial community in MBBR using A. donax as carbon source and biofilm carriers for reverse osmosis concentrate treatment. J. Environ. Sci. 2019, 84, 133-143. [CrossRef] [PubMed]

24. Deng, L.; Guo, W.; Ngo, H.H.; Zhang, X.; Wang, X.C.; Zhang, Q.; Rong, C. New functional biocarriers for enhancing the performance of a hybrid moving bed biofilm reactor-membrane bioreactor system. Bioresour. Technol. 2016, 208, 87-93. [CrossRef] [PubMed]

25. Mao, Y.; Xie, Q.; Zhao, H.; Zhang, Y.; Chen, S.; Tao, L.; Quan, W. Accelerated startup of moving bed biofilm process with novel electrophilic suspended biofilm carriers. Chem. Eng. J. 2017, 315, 364-372. [CrossRef]

26. Song, Z.; Zhang, X.; Ngo, H.H.; Guo, W.; Song, P.; Zhang, Y.; Wen, H.; Guo, J. Zeolite powder based polyurethane sponges as biocarriers in moving bed biofilm reactor for improving nitrogen removal of municipal wastewater. Sci. Total Environ. 2019, 651, 1078-1086. [CrossRef] [PubMed]

27. Ødegaard, H.; Gisvold, B.; Strickland, J. The influence of carrier size and shape in the moving bed biofilm process. Water Sci. Technol. 2000, 4, 383-391. [CrossRef]

28. Shen, Z.; Hu, J.; Wang, J.; Zhou, Y. Biological denitrification using starch/polycaprolactone blends as carbon source and biofilm support. Desalin. Water Treat. 2015, 54, 609-615. [CrossRef]

29. Dupla, M.; Comeau, Y.; Parent, S.; Villemur, R.; Jolicoeur, M. Design optimization of a self-cleaning moving-bed bioreactor for seawater denitrification. Water Res. 2006, 40, 249-258. [CrossRef] [PubMed]

30. Ferrai, M.; Guglielmi, G.; Andreottola, G. Modelling respirometric tests for the assessment of kinetic and stoichiometric parameters on MBBR biofilm for municipal wastewater treatment. Environ. Model. Softw. 2010, 25, 626-632. [CrossRef]

31. Stinson, B.; Peric, M.; Neupane, D.; Laquidara, M.; Locke, E.; Murthy, S.; Bailey, W.; Kharkar, S.; Passarelli, N.; Derminassian, R.; et al. Design and operating considerations for a post denitrification MBBR to achieve limit of technology effluent NOx $<1 \mathrm{mg} / \mathrm{L}$ and effluent TP $<0.18 \mathrm{mg} / \mathrm{L}$. Nutr. Remov. 2009, 4, 1225-1254.

32. Cheng, Z.; Jiang, Y.; Wang, H.; Li, P.; Hang, Q.; Li, L.; Yang, Y.; Zhong, Z. Study on carrier optimum filling ratio of two-stage MBBR for treatment of reverse osmosis concentrate from high-quality water reclamation of WWTP effluent. J. Environ. Eng. Technol. 2017, 7, 285-292.

33. Gu, Q.; Sun, T.; Wu, G.; Li, M.; Wei, Q. Influence of carrier filling ratio on the performance of moving bed biofilm reactor in treating coking wastewater. Bioresour. Technol. 2014, 166, 72-78. [CrossRef] [PubMed]

34. Barwal, A.; Chaudhary, R. Impact of carrier filling ratio on oxygen uptake \& transfer rate, volumetric oxygen transfer coefficient and energy saving potential in a lab-scale MBBR. J. Water Process Eng. 2015, 8, 202-208. 
35. Zhang, X.; Song, Z.; Guo, W.; Lu, Y.; Qi, L.; Wen, H.; Ngo, H.H. Behavior of nitrogen removal in an aerobic sponge based moving bed biofilm reactor. Bioresour. Technol. 2017, 245, 1281-1285. [CrossRef] [PubMed]

36. Quan, F.; Wang, Y.; Wang, T.; Hao, Z.; Chu, L.; Chong, Z.; Chen, H.; Kong, X.; Xing, X.H. Effects of packing rates of cubic-shaped polyurethane foam carriers on the microbial community and the removal of organics and nitrogen in moving bed biofilm reactors. Bioresour. Technol. 2012, 117, 201-207.

37. Piculell, M.; Suarez, C.; Li, C.; Christensson, M.; Persson, F.; Wagner, M.; Hermansson, M.; Jönsson, K.; Welander, T. The inhibitory effects of reject water on nitrifying populations grown at different biofilm thickness. Water Res. 2016, 104, 292-302. [CrossRef]

38. APHA; WEF. Standard Methods for the Examination of Water and Wastewater, 20th ed.; American Public Health Association: Washington, DC, USA, 2005.

39. Liu, Y. Estimating Minimum Fixed Biomass Concentration and Active Thickness of Nitrifying Biofilm. J. Environ. Eng. 1997, 123, 198-202. [CrossRef]

40. Vilar-Sanz, A.; Puig, S.; García-Lledó, A.; Trias, R.; Balaguer, M.D.; Colprim, J.; Bañeras, L. Denitrifying bacterial communities affect current production and nitrous oxide accumulation in a microbial fuel cell. PLoS ONE 2013, 8, e63460. [CrossRef]

41. Scala, D.J.; Kerkhof, L.J. Nitrous oxide reductase (nosZ) gene-specific PCR primers for detection of denitrifiers and three nosZ genes from marine sediments. Fems Microbiol. Lett. 1998, 162, 61-68. [CrossRef]

42. Spellerberg, I.F. Shannon-Wiener Index. In Encyclopedia of Ecology; Elsevier: Amsterdam, The Netherlands, 2008; pp. 3249-3252.

43. Kelly, M.G. Use of similarity measures for quality control of benthic diatom samples. Water Res. 2001, 35, 2784-2788. [CrossRef]

44. Tao, W.; Wen, J.; Han, Y.; Huchzermeier, M.P. Nitrogen Removal in Constructed Wetlands Using Nitritation/Anammox and Nitrification/ Denitrification: Effects of Influent Nitrogen Concentration. Water Environ. Res. 2012, 8, 2099-2105. [CrossRef]

45. Yang, X.L.; Jiang, Q.; Song, H.L.; Gu, T.T.; Xia, M.Q. Selection and application of agricultural wastes as solid carbon sources and biofilm carriers in MBR. J. Hazard. Mater. 2015, 283, 186-192. [CrossRef] [PubMed]

46. Nicolella, C.; Loosdrecht, M.C.M.V.; Heijnen, J.J. Wastewater treatment with particulate biofilm reactors. J. Biotechnol. 2000, 80, 1-33. [CrossRef]

47. Damaraju, S.; Singh, U.K.; Sreekanth, D.; Bhandari, A. Denitrification in biofilm configured horizontal flow woodchip bioreactor: Effect of hydraulic retention time and biomass growth. Ecohydrol. Hydrobiol. 2015, 15, 39-48. [CrossRef]

48. Wang, R.C.; Wen, X.H.; Qian, Y. Influence of carrier concentration on the performance and microbial characteristics of a suspended carrier biofilm reactor. Process Biochem. 2005, 40, 2992-3001. [CrossRef]

49. Hansson, B.; Gunnarson, L. The Use of Industrial By-Products as a Carbon Source for Denitrification. In Chemical Water and Wastewater Treatment; Springer: Berlin/Heidelberg, German, 1990.

50. Shen, Z.; Zhou, Y.; Hu, J.; Wang, J. Denitrification performance and microbial diversity in a packed-bed bioreactor using biodegradable polymer as carbon source and biofilm support. J. Hazard. Mater. 2013, 250-251, 431-438. [CrossRef] [PubMed]

51. Zheng, Y.; Hou, H.J.; Qin, H.L.; Zhu, Y.J.; Wei, W.X. Effect of N application on the abundance of denitrifying genes(narG/nosZ) and $\mathrm{N}_{2} \mathrm{O}$ emission in paddy soil. Acta Ecol. Sin. 2012, 32, 3386-3393. [CrossRef]

52. Henderson, S.L.; Dandie, C.E.; Patten, C.L.; Zebarth, B.J.; Burton, D.L.; Trevors, J.T.; Goyer, C. Changes in Denitrifier Abundance, Denitrification Gene mRNA Levels, Nitrous Oxide Emissions, and Denitrification in Anoxic Soil Microcosms Amended with Glucose and Plant Residues. Appl. Environ. Microbiol. 2010, 76, 2155-2164. [CrossRef]

53. Kitts, C.L. Terminal restriction fragment patterns: A tool for comparing microbial communities and assessing community dynamics. Curr. Issues Intest. Microbiol. 2001, 2, 17-25.

54. Tiedje, J.M.; Asuming-Brempong, S.; Nüsslein, K.; Marsh, T.L.; Flynn, S.J. Opening the black box of soil microbial diversity. Appl. Soil Ecol. 1999, 13, 109-122. [CrossRef]

(C) 2019 by the authors. Licensee MDPI, Basel, Switzerland. This article is an open access article distributed under the terms and conditions of the Creative Commons Attribution (CC BY) license (http://creativecommons.org/licenses/by/4.0/). 